\title{
Government subsidies and corporate innovation performance- Based on the empirical analysis of the new energy automobile industry
}

\author{
Wu Xiaoman ${ }^{1, a}$, Wu Shiqi ${ }^{2}$ \\ ${ }^{1}$ School of Economics Management and Law, Foshan University, Foshan, China \\ ${ }^{2}$ School of Economics Management and Law, Foshan University, Foshan, China
}

\begin{abstract}
This paper selects 112 listed companies in China's a-share new energy vehicle sector from 2009 to 2018 as a research sample, and uses panel data regression analysis models to empirically test the effects of government subsidies on corporate $\mathrm{R} \& \mathrm{D}$ investment and corporate innovation performance. It shows that government subsidies have a significant promotion effect on enterprises R\&D investment; government subsidies have a significant inhibition effect on enterprises' innovation performance.
\end{abstract}

\section{Proposal of the problem}

With the development of economy and society, the level of urbanization continues to improve, the production and sales of fuel vehicles in China are also growing rapidly. By 2019, China's automobile production and sales volume has been the first in the world for 11 consecutive years. At the same time, vehicle exhaust emissions are also increasing year by year, environmental pollution is becoming more and more serious, environmental protection has become a global concern. The key point of environmental protection is to develop new energy and low-carbon economy. Under this background, the traditional automobile industry, which is faced with the scarcity of non-renewable energy such as oil and the increase of pollutant production, urgently needs to reform and innovate, change the industrial structure, only in this way can it have sustainable development in the future. Therefore, new energy vehicles with low energy consumption and low pollution have become the new development direction of traditional automobile industry.

The development of new energy vehicles is one of the national sustainable development strategies. Since 2001, China has a special plan for new energy vehicle technology. In 2012, it also introduced related policies such as granting government subsidies in research and development and sales to strongly support new energy. The development of automobiles. With the support of policies, the number of patent applications related to new energy vehicles has increased year by year, and the production and sales of new energy vehicles have also increased year by year. However, the number of effective patents has not increased as much as expected, and due to the policy Imperfect, there are other aspects of the industry that are not related to research and development after the company obtains subsidies. There are also various levels of 'fraud' in the country. Whether government subsidies can promote the innovation performance of new energy vehicles has become a hot topic.

\section{Literature review and research hypothesis}

\subsection{Research on the impact of government subsidies on R\&D investment}

Gonzalez \& Pazo (2008) used Argentina's manufacturing industry as a sample and found that government subsidies promoted private R\&D investment. Lee and Cin (2010) obtained empirical analysis of different data panels in different countries and concluded that government subsidies had a significant promotion effect on R\&D investment. Garcia (2015) found through research that government subsidies can ease the financing constraints of enterprises and promote enterprises to increase investment in innovation and research and development.

Chen Yanglin et al. (2019) selected data on China's strategic emerging industries from 2010 to 2015. After field inspections, they found that government subsidies have an incentive effect on the research and development investment of state-owned enterprises or non-state-owned enterprises. Gu Yang (2019) passed between 2011-1017 The analysis of micro-data of Chinese high-tech listed companies found that because the strength of government subsidies in different regions is different, the incentive effect on corporate R\&D investment will also be

a158496806@qq.com 
different. The higher the government subsidy intensity, the stronger the incentive effect on enterprises.

Based on the above analysis, this article makes the following assumptions:

H1: In the new energy vehicle industry, government subsidies are positively related to $R \& D$ investment.

\subsection{Impact of government subsidies on corporate innovation performance}

Guangqiang Liu, Xiaojie Zhang et al. (2019) used Chinese zombie companies as a sample from 2007 to 2016. After empirical analysis, it was found that government subsidies had a negative impact on corporate resource profit margins, distorted corporate investment behavior and led to poor corporate performance.

Yang Min and Ning Xiangdong (2018) used regression analysis to study the private companies in China's SME board, and proved that the issuance of government subsidies based on political affiliation will reduce resource utilization and thus affect innovation performance. Zhang Chi (2020) When subsidies and ex post subsidies affect innovation, it was found that ex ante subsidies given before innovation activities did not improve the innovation performance of enterprises.

Based on the above analysis, this article makes the following assumptions:

H2: In the new energy vehicle industry, government subsidies are negatively related to corporate innovation performance.

\subsection{R\&D investment mediation}

Thomson R, P Jensen (2013) found that government subsidies can neither affect $R \& D$ investment nor the innovation performance of enterprises, and have proved the existence of R\&D investment as an intermediary variable from the side.

Fan Xu and Huang Yezhan (2018) conducted an empirical analysis of small and medium-sized enterprises in Guangdong Province and found that the intensity of R\&D investment of enterprises has a significant negative impact on the innovation performance of enterprises. Inputs play a negative mediating role between government subsidies and corporate performance
Based on the above analysis, this article makes the following assumptions:

H3: New energy vehicle industry, R\&D investment plays a mediating role on the relationship between government subsidies and corporate innovation performance.

\section{Research design}

\subsection{Sample selection and data source}

This article selects the listed companies of new energy vehicles from 2009 to 2018 as the research object. The sample data comes from the Guotai'an database and Sina Finance. After manual screening and integration, 112 new energy vehicle listed companies were obtained, and 617 sample observations were obtained. (1) Exclude listed companies ST and *ST to reduce errors; (2) Exclude samples with missing financial data; (3) Exclude B-share and H-share new energy automobile listed companies.

\subsection{Main research variables}

- Explained variable: Enterprise innovation performance (ROA). Innovation is the core of the new energy automobile industry, and its innovation performance is equivalent to operating performance.

- Explanatory variable: Government subsidy (Sub). This article collects the government subsidy data for the second-level subject "Government subsidy" in the "Non-operating income" subject of the income statement. In order to match the R\&D input index (R\&D), measure government subsidy The indicator of strength is the ratio of government subsidies to operating income.

- Intermediate variable: R\&D investment. This article uses the ratio of the amount of $R \& D$ investment disclosed in the annual financial statements of listed companies to operating income to measure R\&D investment. The higher the value, the stronger the R\&D effort.

TABLE I VARIABLE DESCRIPTION

\begin{tabular}{l|c|c|c}
\hline \multicolumn{4}{c}{ Model Variable Selection Table } \\
\hline Variable attributes & Variable name & Variable symbol & definition \\
\hline Explained variable & Innovation performance & ROA & Net profit / average total assets \\
\hline Explanatory variables & Government subsidies & Sub & Government subsidy / operating income \\
\hline Mediation variable & R & R\&D & R \& D investment / operating income \\
\hline \multirow{2}{*}{ Control variable } & Enterprise size & Size & Ln Total Assets \\
\cline { 2 - 4 } & Assets and liabilities & Lev & Total Ending Liabilities / Total Ending Assets \\
\cline { 2 - 4 } & Growth & Growth & Operating income growth rate \\
\hline
\end{tabular}




\subsection{Empirical model}

In order to test the relationship between government subsidies and R\&D investment, this paper constructs the following regression model:

\section{$R \& D=a+\beta_{1}$ Sub $+\beta_{2}$ Size $+\beta_{3}$ Lev $+\beta_{4}$ Growt $+\varepsilon$}

If ${ }^{\beta_{1}}$ Significantly positive or (negative), indicating that government subsidies are significantly positive (negative) related to R\&D investment, otherwise, there is no significant correlation between the two.

To test the relationship between fake government subsidies and corporate innovation performance, this paper builds the following regression model:

$$
R O A=a+\beta_{1} S u b+\beta_{2} \text { Size }+\beta_{3} L \text { ev }+\beta_{4} \text { Growth }+\varepsilon
$$

If ${ }^{\beta_{1}}$ Significantly positive or (negative), indicating that government subsidies are significantly positive (negative) related to innovation performance, otherwise, there is no significant correlation between the two.

In order to test the role of R\&D investment in the mediating effect of government subsidies on the innovation performance of enterprises, this article constructs a regression model:

$$
R O A=a+\beta_{1} S u b+\beta_{2} R \& D+\beta_{3} L e v+\beta_{4} \text { Growth }+\beta_{5} \text { Size }+\varepsilon
$$

in case ${ }^{\beta_{2}}<0$, it shows that $\mathrm{R} \& \mathrm{D}$ income has a mediating effect on the relationship between government subsidies and innovation performance. On this basis, ${ }_{\text {if }}{ }^{\beta_{1}}$ Significant, it proves that there is a partial mediation effect; if ${ }^{\beta_{1}}$ Not significant, it proves that there is a full mediation effect.

\section{Empirical test results and analysis}

\subsection{Descriptive analysis}

As can be seen from Table II, the minimum and maximum values of $R \& D$ investment are 0.001 and 0.169 respectively, indicating that there is a large difference in the intensity of independent research and development and the level of innovation between companies, and some companies do not focus on innovation and research and development. In terms of government subsidies, the minimum value is 0 and the maximum value is 0.165 , which indicates that the government's subsidy strength for various enterprises is different.

TABLE II DESCRIPTIVE ANALYSIS

\begin{tabular}{lllllll}
\hline \multicolumn{7}{c}{ Basic index } \\
\hline name & Sample size & $\begin{array}{l}\text { Minimum } \\
\text { value }\end{array}$ & Max & Average & $\begin{array}{l}\text { Standard } \\
\text { deviation }\end{array}$ & Median \\
\hline R\&D & 617 & 0.001 & 0.169 & 0.037 & 0.016 & 0.037 \\
ROA & 617 & -0.531 & 0.215 & 0.056 & 0.055 & 0.053 \\
Sub & 617 & 0 & 0.165 & 0.009 & 0.012 & 0.006 \\
Growth & 617 & -0.447 & 429.036 & 0.842 & 17.274 & 0.106 \\
Lev & 617 & 0.063 & 0.982 & 0.44 & 0.186 & 0.435 \\
Size & 617 & 19.632 & 27.386 & 22.36 & 1.439 & 22.081 \\
\hline
\end{tabular}

\subsection{Correlation analysis}

As can be seen from Table III, the coefficient of government subsidies and R\&D investment is 0.350 , and there is a significant positive correlation between the two at the level of $1 \%$; the coefficients between government subsidies and total net asset rate and R\&D investment and total net asset rate are -0.105 and -0.113 , both have a significant negative correlation at the $1 \%$ level.

TAble III Pearson correlation analysis

\begin{tabular}{lllllllll}
\hline & $\begin{array}{l}\text { average } \\
\text { value }\end{array}$ & $\begin{array}{l}\text { Standard } \\
\text { deviation }\end{array}$ & R\&D & ROA & Sub & Growth & Size & Lev \\
\hline R\&D & 0.037 & 0.016 & 1 & & & & & \\
ROA & 0.056 & 0.055 & $-0.113 * *$ & 1 & & & & \\
Sub & 0.009 & 0.012 & $0.350 * *$ & $-0.105 * *$ & 1 & & & \\
Growth & 0.842 & 17.274 & 0.074 & -0.034 & $0.151 * *$ & 1 & & \\
Size & 22.36 & 1.439 & $-0.150 * *$ & -0.049 & $-0.083 *$ & 0.062 & 1 & \\
Lev & 0.44 & 0.186 & $-0.171 * *$ & $-0.372 * *$ & -0.049 & 0.041 & $0.529 * *$ & 1 \\
\hline \multicolumn{7}{c}{$* p<0.05 * * p<0.01$} \\
\hline
\end{tabular}




\subsection{Regression Analysis}

\subsubsection{Regression Analysis of the Impact of Government Subsidies on R\&D Investment}

From the Table IV, we can adjust $\mathrm{R}^{2}$ to 0.144 , which proves that the above variables can explain the cause of the $14.4 \%$ change in R\&D. When the model was tested for $\mathrm{F}$, it was found that the model passed the $\mathrm{F}$ test $(\mathrm{F}=$
$26.959, \mathrm{p}=0.000<0.05$ ), indicating that the government subsidies At least one of the company's size, enterprise size, asset-liability ratio, and growth has an impact on R\&D investment. From the table, we can see that the regression coefficient between government subsidies and $\mathrm{R} \& \mathrm{D}$ investment is $0.447>0$, which means that government subsidies have a significant positive correlation with R\&D investment. Relationship, suppose 1 holds.

TABLE IV REGRESSION ANALYSIS RESULTS OF GOVERNMENT SUBSIDIES AND R\&D INVESTMENT

\begin{tabular}{|c|c|c|c|c|c|c|c|c|}
\hline \multicolumn{9}{|c|}{ Linear regression analysis results $(n=617)$} \\
\hline ث & $\begin{array}{l}\text { Regression } \\
\text { coefcients }\end{array}$ & $\begin{array}{l}\text { Standard } \\
\text { error }\end{array}$ & $\mathrm{t}$ & $\mathrm{p}$ & VIF & $\mathbf{R}^{2}$ & Adjust $\mathrm{R}^{2}$ & $\checkmark F$ \\
\hline constant & 0.053 & 0.011 & 5.054 & $0.000 * *$ & - & & & \\
\hline Sub & 0.447 & 0.051 & 8.831 & $0.000 * \star$ & 1.032 & & & $\mathrm{~F}(4,612)=$ \\
\hline Growth & 0 & 0 & 0.86 & 0.39 & 1.029 & 0.15 & 0.144 & 26.959, \\
\hline Lev & -0.011 & 0.004 & -2.848 & $0.005 * *$ & 1.388 & & & $\mathrm{p}=0.000$ \\
\hline Size & -0.001 & 0.001 & -1.329 & 0.184 & 1.399 & & & \\
\hline \multicolumn{9}{|c|}{ Dependent variable: $R \& D$} \\
\hline \multicolumn{9}{|c|}{$\mathrm{D}-\mathrm{W}$ value: 0.816} \\
\hline \multicolumn{9}{|c|}{$* \mathrm{p}<0.05 * * \mathrm{p}<0.01$} \\
\hline
\end{tabular}

\subsubsection{Regression analysis results of government subsidies and R\&D investment}

According to the number in the Table $\mathrm{V}$, we can adjust $\mathrm{R}^{2}$ to 0.176 , that is, all the variables mentioned in the table above can explain the reason for the change of ROA $17.6 \%$. When the model is tested by $\mathrm{F}$, it is found that the model passes the $\mathrm{F}$ test $(\mathrm{F}=33.881, \mathrm{p}=0.000$ $<0.05$ ), Which indicates that at least one of all variables will have an impact on ROA. From the table, it can be found that the regression coefficients of ROA, government subsidies, and asset-liability ratios are -0.492 and -0.141 , respectively, and the regression coefficients of enterprise size. It is 0.007 , which means that there is a significant negative impact relationship between ROA, government subsidies, and asset-liability ratio, and a significant positive impact relationship with the size of the enterprise. Hypothesis 2 holds.

TABLE V ANALYSIS OF REGRESSION RESULTS OF GOVERNMENT SUBSIDIES AND CORPORATE INNOVATION PERFORMANCE

\begin{tabular}{|c|c|c|c|c|c|c|c|}
\hline \multirow[b]{2}{*}{$\mathrm{e}$} & \multicolumn{7}{|c|}{ Linear regression analysis results $(n=617)$} \\
\hline & $\begin{array}{l}\text { Regression } \\
\text { coefcients }\end{array}$ & $\begin{array}{l}\text { Standard } \\
\text { error }\end{array}$ & $\mathrm{t}$ & $\mathrm{p}$ & VIF $\mathbf{R}^{2}$ & Adjust $\mathrm{R}^{2}$ & $\hookleftarrow \mathrm{F}$ \\
\hline constant & -0.044 & 0.034 & -1.29 & 0.198 & - & & \\
\hline Sub & -0.492 & 0.165 & -2.989 & $0.003 * *$ & 1.032 & & $F(4,612)=$ \\
\hline Growth & -0 & 0 & -0.275 & 0.784 & $1.029 \quad 0.181$ & 0.176 & 33.881, \\
\hline Lev & -0.141 & 0.013 & -11.161 & $0.000 * *$ & 1.388 & & $\mathrm{p}=0.000$ \\
\hline \multirow[t]{4}{*}{ Size } & 0.007 & 0.002 & 4.537 & $0.000 * *$ & 1.399 & & \\
\hline & \multicolumn{7}{|c|}{ Dependent variable: $\mathrm{ROA}$} \\
\hline & \multicolumn{7}{|c|}{ D-W value: 1.340} \\
\hline & \multicolumn{7}{|c|}{$* p<0.05 * * p<0.01$} \\
\hline
\end{tabular}




\subsubsection{Analysis of regression results for hypothesis 3}

The Table VI shows the regression results of models (1)(2)(3). From the above table, it can be seen that in model (1), the regression coefficient of government subsidies and research inputs is $0.447 * *$, which is significant at the $1 \%$ level, indicating that government subsidies have a significant positive impact on research inputs. In model (2), the regression coefficient of government subsidy and corporate innovation performance is $-0.492 * *$, which is significant at the level of $1 \%$, which means that government subsidy has a significant negative impact on corporate innovation subsidy. In model (3), after adding a variable of R\&D investment to Model (2), the regression coefficient of government subsidy and innovation performance changed from $-0.492 * *$ to -0.273 , and the regression coefficient of R\&D investment and innovation performance was $-0.492 * *$. It is significant at the level of $1 \%$. This indicates that after adding R\&D investment variables, the effect of government subsidies on innovation performance has been reduced, and R\&D investment has a significant negative relationship to innovation performance, which means that R\&D investment starts between government subsidies and innovation performance Play a full mediating role.

TABLE VI ANALYSIS OF REGRESSION RESULTS FOR HYPOTHESIS 3

\begin{tabular}{|c|c|c|c|c|c|c|c|c|c|}
\hline \multicolumn{10}{|c|}{ Intermediate effect model test $(n=617)$} \\
\hline \multirow[b]{2}{*}{$\hookleftarrow$} & \multicolumn{3}{|l|}{$R \& D$} & \multicolumn{3}{|l|}{$\mathrm{ROA}$} & \multicolumn{3}{|l|}{ ROA } \\
\hline & $\begin{array}{l}\text { Regression } \\
\text { coefficient }\end{array}$ & $t$ & $\mathrm{p}$ & $\begin{array}{l}\text { Regression } \\
\text { coefficient }\end{array}$ & $t$ & $\mathbf{p}$ & Regression coefficient & $t$ & $\mathrm{p}$ \\
\hline constant & $0.053 * *$ & 5.054 & 0 & -0.044 & -1.29 & 0.198 & -0.018 & -0.522 & 0.602 \\
\hline Growth & 0 & 0.86 & 0.39 & -0 & -0.275 & 0.784 & -0 & -0.146 & 0.884 \\
\hline Lev & $-0.011 * \star$ & -2.848 & 0.005 & $-0.141 * \star$ & -11.161 & 0 & $-0.147 \star *$ & -11.639 & 0 \\
\hline Size' & -0.001 & -1.329 & 0.184 & $0.007 * *$ & 4.537 & 0 & $0.007 \star \star$ & 4.376 & 0 \\
\hline Sub & $0.447 * *$ & 8.831 & 0 & $-0.492 \star * \star$ & -2.989 & 0.003 & -0.273 & -1.576 & 0.116 \\
\hline$R \& D$ & & & & & & & $-0.492 * *$ & -3.776 & 0 \\
\hline $\mathbf{R}^{2}$ & 0.15 & & & 0.181 & & & 0.2 & & \\
\hline Adjust $R^{2}$ & 0.144 & & & 0.176 & & & 0.193 & & \\
\hline F value & $\begin{array}{l}F(4,612)=26 \\
p=0.000\end{array}$ & 959 & & $\begin{array}{l}F(4,612)=33 \\
p=0.000\end{array}$ & .881, & & $\begin{array}{l}F(5,611)=30.544 \\
p=0.000\end{array}$ & & \\
\hline
\end{tabular}

\subsubsection{Robustness test}

The result of the model's robustness analysis is that the government subsidy has a significant positive correlation with R\&D investment at a level of $1 \%$, and a significant negative correlation with the total net asset interest rate. R\&D investment plays an intermediary role in the relationship between the two, and it is related to the regression analysis. The results are consistent, indicating that the conclusions are reliable and three assumptions hold.

\section{5 lysis conclusion}

This article studies the impact of government subsidies on corporate innovation performance. After empirical analysis of data panels of 112 A-share new energy vehicle listed companies from 2009 to 2018, the following conclusions are drawn: (1) Government subsidies have a positive correlation with R\&D investment; (2) Government subsidies have a negative correlation with ROA; (3) R\&D input plays an intermediary role in the negative impact of government subsidies on corporate innovation performance, and government subsidies have an indirect impact on innovation performance through R\&D inputs. Therefore, this article considers that the government grants new energy vehicles Enterprise subsidies can indeed increase the enthusiasm of enterprises for research and development and increase their investment in innovation research and development. However, because government subsidies have weakened the role of market regulation, innovation has not brought expected performance.

\section{References}

1. Garcia Pires, A.J.Competitiveness $\sim$ shifting effects and the prisoner's dilemma in international R\&D subsidy wars.International Economics, 2015:32 49

2. Gorg H., Strobl E. The effect of R\&D subsidies on private R\&D [J]. Economica, 2007,74(294):215-234

3. Lee EY, Cin BC. The Effect of Risk - sharing Government Subsidy on CORPORATE R\&D Investment: Empirical Evidence from Korea [J], 
Tcvhnological Forecasting\&Social Change, 2010,(77):881-890

4. Wei Zhihua, Zhao Yueru, Wu Yuhui. Fiscal subsidy: "pie" or "trap"? _ An empirical study based on financing constraints vs. overinvestment perspectives [j]. Financial Research, 2015 (12): 18-29.

5. Fang Min. Empirical Research on the Impact of Government Subsidies on Enterprise Performance- Based on China's New Energy Vehicle Manufacturing Industry Data Analysis [j]. Shanxi Finance \& Taxation, 2019 (12): 40-44.

6. Li Lei. Research on the Impact of Government R\&D Subsidies on the Technology Innovation Output of New Energy Vehicle Industry [j]. Science and Technology Management Research, 2018, 38 (17): 160-166.
7. Ying Xiaoni. Research on the impact of government subsidies on new energy vehicle enterprises' innovation investment [j]. China Price, 2020 (02): 33-35 + 39. [8] Hu Guoheng, Liu Yuwei. Government support promotes new energy Development of the industry [j] .Finance and Accounting Monthly, 2017 (18): 36-41.

8. Zhang Yi .Technical innovation incentive effect of government subsidies_-Evidence from listed agricultural companies [j] .Agricultural Technology \& Economy, 2020 (01): 92-101.

9. Gu Yang. The impact of government subsidies on corporate innovation behavior: based on micro data of China's high-tech listed companies from 2011 to 2017 [j]. Science \& Technology Progress and Policy, 2019, 36 (19): 100-108. 